\title{
Tropic Responses of Fungi to Wood Volatiles
}

\author{
By GREGORY MOWE, BERNARD KING* AND STEPHEN J. SENN \\ Department of Molecular \& Life Sciences, Dundee College of Technology, \\ Dundee DDI $1 H G$, U.K.
}

(Received 21 June 1982; revised 20 August 1982)

\begin{abstract}
Sapwood blocks of lime (Tilia vulgaris) and pine (Pinus sylvestris) placed to one side of growing colonies of several wood decay fungi markedly influenced their hyphal extension patterns, particularly by causing positive or negative tropic responses. A method was devised to measure and quantify these responses and analyse them statistically. Chemotropic responses were demonstrated by Chaetomium globosum, Trichoderma viride, Serpula lacrymans and Coniophora puteana in the presence of air-dried and heat-dried wood but not by Coriolus versicolor or Humicola grisea. The implications of chemotropism as a factor influencing the invasion and colonization of wood are discussed.
\end{abstract}

\section{INTRODUCTION}

Observations on nitrogen accumulation in unpreserved and preserved wood, both in the field (Henningsson \& Nilsson, 1976) and in the laboratory (King et al., 1981), have led to the suggestion that soft rot of wood in soil is an invasive process in which the biotic connection between wood and soil is maintained. Because of quantitative relationships between nitrogen uptake and soluble nutrients present in wood, King et al. (1981) suggested that such nutrients acted as chemotropic and chemotactic attractants to some members of the soil microflora. This was supported by pure culture experiments in which both gross stimulation and oriented hyphal extension in the direction of the wood by Chaetomium globosum Kunze was observed. Such effects, if general, may be of critical importance in understanding the invasion and colonization of wood in the field.

This paper describes the detection and statistical analysis of chemotropic responses by fungi to wood. Previous studies with wood and wood volatiles have largely concentrated on stimulatory or inhibitory effects of wood, and tropic responses of fungi have not received major emphasis. More importantly, by the nature of the experimental designs used to date, these responses may not occur or would be difficult to detect.

\section{METHODS}

Preparation of wood blocks. Freshly felled, quartersawn planks of two wood species, Scots pine, Pinus sylvestris L., and lime, Tilia vulgaris Hayne, were either stored in polythene bags at $-18^{\circ} \mathrm{C}$ or dried in a fan oven at $40^{\circ} \mathrm{C}$ to $12 \%$ moisture content before storage in a ventilated cupboard under ambient room conditions for periods of not less than 6 months. Blocks measuring $10 \times 10 \times 5 \mathrm{~mm}$, prepared from the sapwood of both fresh and dried wood, were cut so that the $10 \times 5 \mathrm{~mm}$ faces were in tangential longitudinal and transverse planes respectively and the 10 $\times 10 \mathrm{~mm}$ faces were in radial longitudinal section. Half the fresh blocks and half the blocks dried at $40^{\circ} \mathrm{C}$ were further heated in an oven at $102^{\circ} \mathrm{C}$ for $12 \mathrm{~h}$, giving four treatments for both wood species: fresh blocks, fresh blocks dried at $102{ }^{\circ} \mathrm{C}$, blocks dried at $40^{\circ} \mathrm{C}$, and blocks dried at $40{ }^{\circ} \mathrm{C}$ then heated to $102^{\circ} \mathrm{C}$.

Exposure of fungi to wood. Six fungi were used: Coriolus versicolor (L. ex Fr.) Quel. FPRL 28A, Serpula lacrymans (Fries) Karst. FPRL 12C, Coniophora puteana (Schum. ex Fr.) Karst. FPRL 11E, Chaetomium globosum Kunze FPRL 70K, Humicola grisea Traen and Trichoderma viride Pers. ex Fr. They were grown in $90 \mathrm{~mm}$ diameter Petri dishes containing $20 \mathrm{ml}$ malt extract agar (Oxoid) at $2 \%(\mathrm{w} / \mathrm{v})$ strength for the basidiomycetes and at $3 \%$ for nonbasidiomycetes. The plates were inoculated at their centres with $5 \mathrm{~mm}$ cores of each organism and incubated in the 


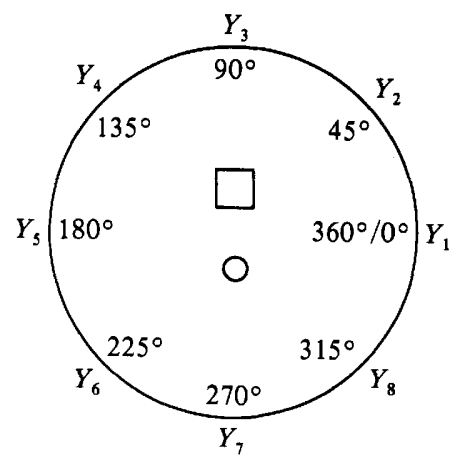

Fig. 1. Arrangement of angular measurement intervals and the sequence in which measurements were taken. The small circle denotes the inoculum and the square denotes the bait.

dark at $25^{\circ} \mathrm{C}$ except for $S$. lacrymans which was incubated at $22^{\circ} \mathrm{C}$. Plugs of each culture ( 5 mm diameter) were removed with a sterile cork borer from the margins of growing colonies and transferred to $5 \mathrm{~mm}$ discs of sterile filter paper on the surface of Czapek Dox agar in a Petri dish. A support constructed from $2 \mathrm{~mm}$ diameter pliable plastic-coated wire formed into a $\mathrm{Z}$ shape was positioned at a distance of $12.5 \mathrm{~mm}$ from the centre of each inoculum. The wood blocks were placed on these supports with a $10 \times 10 \mathrm{~mm}$ face in contact with the support and a $10 \times 5 \mathrm{~mm}$ transverse face towards the inoculum. Five replicate plates for each wood type and drying regime were exposed to each test fungus and incubated at $25^{\circ} \mathrm{C}$, except $S$. lacrymans plates which were incubated at $22^{\circ} \mathrm{C}$. Controls were arranged identically except that blocks of moist sponge or glass of the same dimensions replaced the wood. A supplementary experiment using Chaetomium globosum was undertaken in which blocks were placed at a range of distances between 5 and $40 \mathrm{~mm}$ from the inoculum, in increments of $5 \mathrm{~mm}$, to determine the effect of distance on the growth response.

Measurement of growth. Eight radial measurements, $Y_{1}-Y_{8}$, were taken for the five replicate plates of each treatment. Measurements were made from centres of inocula to limits of hyphal extension at $45^{\circ}$ intervals in an anticlockwise order starting at $Y_{1}$ (Fig. 1). Colony radii were then plotted in sequence against measurement intervals. Times at which measurements were made varied with the growth rates of the fungi and ranged from $25 \mathrm{~h}$ for $T$. viride to $120 \mathrm{~h}$ for $S$. lacrymans.

A simple model of the form $Y=\gamma+\alpha \sin (X+\beta)$ was used to describe the pattern of growth. The parameter $\gamma$ is the mean radius of the colony and is an indicator of gross stimulation and inhibition. The parameter $\alpha$, the amplitude (as used in the description of a sine wave), is a measure of the degree of distortion or differential growth and indicates the extent to which the colony departs from circularity. $X$ is the number of degrees in an anticlockwise direction from $0^{\circ}$ at which $Y$ is measured, and the parameter $\beta$ is the number of degrees in a clockwise direction from the location of $Y_{3}$ to the point at which maximum hyphal extension occurs.

\section{RESULTS AND DISCUSSION}

Fungal colonies on agar plates generally grow with radial symmetry, and colony radii measured at regular intervals when plotted in sequence against measurement intervals follow straight lines parallel to $X$ axes. The radii of colonies distorted by stimuli when similarly plotted approximately follow sine waves. Examples of growth patterns for stimulated and unstimulated colonies of Chaetomium globosum are shown in Fig. 2. Analyses of these sine waves indicate the amounts and directions of distortions, their statistical significances and whether they are related to stimuli.

A planned comparison was used to determine whether mean colony radii and differential growth values of fungi in the presence of wood were significantly different from those exposed to inert controls (Tables 1 and 2). Radial hyphal extension by Chaetomium globosum, S. lacrymans and Coniophora puteana was significantly stimulated or inhibited in the presence of wood but Coriolus versicolor and $H$. grisea were unaffected. Significant differential growth was demonstrated by the four organisms in Table 2 ; either orientation of growth towards wood baits or alternatively growth in an opposite direction occurred. Phase data (directionality) generally varied between $\pm 15^{\circ}$ of $Y_{3}$ when hyphal extension was maximized towards baits and between $\pm 15^{\circ}$ of $Y_{7}$ when hyphal extension was maximized away from baits. 


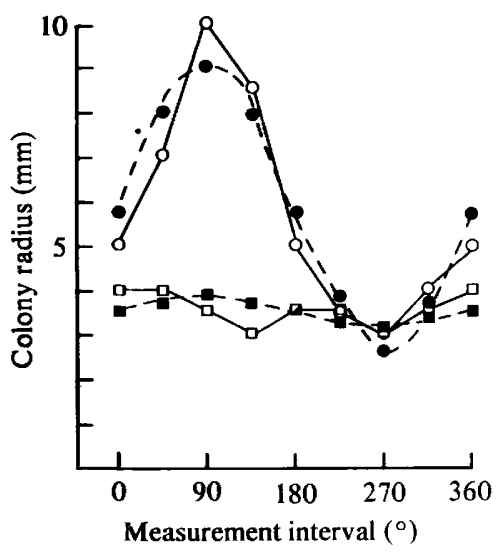

Fig. 2. Growth pattern of Chaetomium globosum in the presence of heat-dried $\left(40^{\circ} \mathrm{C}\right)$ lime sapwood $(\mathrm{O})$ and glass $(\square)$ baits placed at the $90^{\circ}$ position to the inoculum. The points represent mean colony radii measured from the centres of the inocula to the limits of hyphal extension, at the measurement intervals indicated. Sine waves of best fit are shown for colonies stimulated by the heat-dried lime sapwood (O) and for the unstimulated control ( $\square$ ).

Table 1. Mean radii of fungal colonies exposed to either fresh or variously dried lime and pine sapwood blocks and inert controls

Figures represent means of five replicates and their standard deviations. $t$ values for the planned comparison indicate significances of differences between growth patterns of fungi exposed to wood baits and inert controls $\left({ }^{* *}\right.$, significant at $0 \cdot 1 \% ;{ }^{* *}$, significant at $\left.1 \%\right)$.

\begin{tabular}{|c|c|c|c|c|c|c|c|}
\hline \multirow[b]{2}{*}{ Organism } & \multicolumn{6}{|c|}{ Colony radius $(\mathrm{mm})$ with indicated wood treatment $\dagger$} & \multirow[b]{2}{*}{$t$} \\
\hline & type & Fresh & Fresh $\rightarrow 102^{\circ} \mathrm{C}$ & $40^{\circ} \mathrm{C}$ & $40^{\circ} \mathrm{C} \rightarrow 120^{\circ} \mathrm{C}$ & Control & \\
\hline Chaetomium globosum & $\begin{array}{l}\text { Lime } \\
\text { Pine }\end{array}$ & $\begin{array}{l}5.3 \pm 0.45 \\
4.4 \pm 0.49^{a}\end{array}$ & $\begin{array}{l}5.7 \pm 0.18 \\
5.7 \pm 0.08\end{array}$ & $\begin{array}{l}6.0 \pm 0.09 \\
5.8 \pm 0.30\end{array}$ & $\begin{array}{l}5.8 \pm 0.67 \\
6.0 \pm 0.31\end{array}$ & $4.2 \pm 0.38$ & $8 \cdot 05^{* * *}$ \\
\hline Serpula lacrymans $\ddagger$ & $\begin{array}{l}\text { Lime } \\
\text { Pine }\end{array}$ & $\begin{array}{l}6.7 \pm 0.54^{a} \\
6.8 \pm 0.26^{a}\end{array}$ & $\begin{array}{l}4.4 \pm 0.25 \\
6.6 \pm 0.32^{a}\end{array}$ & $\begin{array}{l}3.7 \pm 0.23 \\
5.1 \pm 0.26\end{array}$ & $\begin{array}{l}4.3 \pm 0.51 \\
5.6 \pm 0.93\end{array}$ & $6.7 \pm 0.25$ & $-6 \cdot 25^{* * *}$ \\
\hline Coniophora puteana $\ddagger$ & $\begin{array}{l}\text { Lime } \\
\text { Pine }\end{array}$ & $\begin{array}{l}4 \cdot 8 \pm 0 \cdot 80^{a} \\
5 \cdot 3 \pm 0.09\end{array}$ & $\begin{array}{l}4.8 \pm 0.60^{a} \\
4.6 \pm 0.44^{a}\end{array}$ & $\begin{array}{l}4.8 \pm 0.37^{a} \\
5.2 \pm 0.21\end{array}$ & $\begin{array}{l}4.7 \pm 0.34^{a} \\
5.5 \pm 0.14\end{array}$ & $4.4 \pm 0.28$ & $2 \cdot 89^{* *}$ \\
\hline Trichoderma viride & $\begin{array}{l}\text { Lime } \\
\text { Pine }\end{array}$ & $\begin{array}{l}9.5 \pm 0.32 \\
9.4 \pm 0.25\end{array}$ & $\begin{array}{r}9 \cdot 7 \pm 0.37^{a} \\
10 \cdot 4 \pm 0.64^{a}\end{array}$ & $\begin{array}{l}10 \cdot 8 \pm 0.41 \\
10.5 \pm 0.27\end{array}$ & $\begin{array}{l}10 \cdot 0 \pm 0.43^{a} \\
10 \cdot 5 \pm 0.64^{a}\end{array}$ & $10 \cdot 0 \pm 0.06$ & $0 \cdot 42$ \\
\hline Coriolus versicolor & $\begin{array}{l}\text { Lime } \\
\text { Pine }\end{array}$ & $\begin{array}{l}11 \cdot 0 \pm 0.71^{a} \\
12 \cdot 0 \pm 0.50^{a}\end{array}$ & $\begin{array}{l}11 \cdot 0 \pm 0.35^{a} \\
12 \cdot 0 \pm 0 \cdot 70^{a}\end{array}$ & $\begin{array}{l}12.2 \pm 0.44^{a} \\
11.4 \pm 0.54^{a}\end{array}$ & $\begin{array}{l}11 \cdot 5 \pm 0.35^{a} \\
11.2 \pm 0.76^{a}\end{array}$ & $11.6 \pm 0.74$ & - \\
\hline Humicola grisea & $\begin{array}{l}\text { Lime } \\
\text { Pine }\end{array}$ & $\begin{array}{l}6.8 \pm 0.27^{a} \\
6.8 \pm 0.44^{a}\end{array}$ & $\begin{array}{l}6.6 \pm 0.22^{a} \\
6.8 \pm 0.26^{a}\end{array}$ & $\begin{array}{l}6.9 \pm 0.42^{a} \\
6.3 \pm 0.57^{a}\end{array}$ & $\begin{array}{l}7.3 \pm 0.27^{a} \\
6.1 \pm 0.22^{a}\end{array}$ & $7 \cdot 0 \pm 0.35$ & - \\
\hline
\end{tabular}

- , Not tested.

$\dagger$ Values marked with a superscript $a$ are not significantly different from the control at the $5 \%$ level.

$\ddagger$ Significant differences between wood types indicated by factorial analysis.

A factorial analysis indicated that dried rather than fresh wood caused major alterations in the patterns of hyphal extension and that wood species also exerted some influence. Chaetomium globosum and $T$. viride showed stimulated growth towards dried lime and pine; Coniophora puteana was stimulated only by pine and $S$. lacrymans was inhibited by dried lime.

The results of this investigation clearly show that when fungi are exposed to eccentrically placed wood blocks directional growth takes place. Growth on the sides of colonies of Chaetomium globosum and $T$. viride closest to the wood blocks was stimulated, resulting in increased hyphal length, whereas on the sides of colonies away from wood baits hyphal length remained unaffected in linear terms. In strongly stimulated colonies of Chaetomium globosum 
Table 2. Mean differential growth values ( $\alpha$ ) of fungal colonies exposed to either fresh or variously dried lime and pine sapwood blocks and inert controls

Figures represent means of five replicates and their standard deviations. Negative values indicate growth away from the bait. Figures in parentheses are the dimensionless values for differential growth $(\delta)$ defined in the text. $t$ values for the planned comparison indicate significances of differences between growth patterns of fungi exposed to controls and wood baits $\left({ }^{* * *}\right.$, significant at $0 \cdot 1 \%$; ${ }^{* *}$, significant at $1 \%$ ).

Organism $\quad \begin{aligned} & \text { Wood } \\ & \text { type }\end{aligned} \overbrace{\text { Fresh }}^{\text {Fresh } \rightarrow 102^{\circ} \mathrm{C} \quad 40^{\circ} \mathrm{C} \quad 40^{\circ} \mathrm{C} \rightarrow 102^{\circ} \mathrm{C} \quad \text { Control }} t$

\begin{tabular}{|c|c|c|c|c|c|c|c|}
\hline Chaetomium globosum & Lime & $\begin{array}{c}1 \cdot 6 \pm 0 \cdot 18^{a} \\
(0 \cdot 29) \\
1 \cdot 2 \pm 0 \cdot 30^{a} \\
(0 \cdot 28)\end{array}$ & $\begin{array}{c}3 \cdot 1 \pm 0.32 \\
(0.55) \\
3 \cdot 0 \pm 0.29 \\
(0.52)\end{array}$ & $\begin{array}{c}3 \cdot 3 \pm 0 \cdot 26 \\
(0 \cdot 55) \\
3 \cdot 1 \pm 0 \cdot 55 \\
(0.54)\end{array}$ & $\begin{array}{c}2 \cdot 6 \pm 0.33 \\
(0 \cdot 45) \\
3 \cdot 6 \pm 0 \cdot 21 \\
(\mathbf{0} \cdot 60)\end{array}$ & $\begin{array}{c}1 \cdot 3 \pm 0.38 \\
(0 \cdot 31)\end{array}$ & $8.97 * * *$ \\
\hline Serpula lacrymans $\ddagger$ & $\begin{array}{l}\text { Lime } \\
\text { Pine }\end{array}$ & $\begin{array}{c}0.6 \pm 0.27 \\
(0.09) \\
0.7 \pm 0.40 \\
(0.11)\end{array}$ & $\begin{array}{c}-1.9 \pm 0.33 \\
(-0.43) \\
0.0 \pm 0.96^{a} \\
(0.00)\end{array}$ & $\begin{array}{c}-0.5 \pm 0.67 \\
(-0.14) \\
-0.9 \pm 0.28 \\
(-0.18)\end{array}$ & $\begin{array}{c}-0.9 \pm 0.24 \\
(-0.20) \\
-0.8 \pm 0.6 \\
(-0.15)\end{array}$ & $\begin{array}{c}-0 \cdot 1 \pm 0 \cdot 14 \\
(-0 \cdot 01)\end{array}$ & $-1 \cdot 68$ \\
\hline Coniophora puteana $\ddagger$ & $\begin{array}{l}\text { Lime } \\
\text { Pine }\end{array}$ & $\begin{array}{c}0.1 \pm 0.20^{a} \\
(0.02) \\
0.3 \pm 0.23^{a} \\
(0.06)\end{array}$ & $\begin{array}{c}0.3 \pm 0.50^{a} \\
(0.07) \\
0.6 \pm 0.17 \\
(0.13)\end{array}$ & $\begin{array}{c}0.8 \pm 0.23 \\
(0.17) \\
1.0 \pm 0.19 \\
(0.19)\end{array}$ & $\begin{array}{c}0.2 \pm 0.22^{a} \\
(0.04) \\
1.4 \pm 0.36 \\
(0.25)\end{array}$ & $\begin{array}{c}-0.1 \pm 0.28 \\
(-0.02)\end{array}$ & $4 \cdot 87^{* *}$ \\
\hline Trichoderma viride & $\begin{array}{l}\text { Lime } \\
\text { Pine }\end{array}$ & $\begin{array}{c}0.3 \pm 0.29^{a} \\
(0.03) \\
0.5 \pm 0.63^{a} \\
(0.05)\end{array}$ & $\begin{array}{c}1 \cdot 2 \pm 0.42 \\
(0 \cdot 12) \\
1 \cdot 0 \pm 0.43^{a} \\
(0 \cdot 10)\end{array}$ & $\begin{array}{c}1 \cdot 3 \pm 0 \cdot 22 \\
(0 \cdot 12) \\
1 \cdot 3 \pm 0 \cdot 32 \\
(0 \cdot 12)\end{array}$ & $\begin{array}{c}1 \cdot 3 \pm 0 \cdot 15 \\
(0 \cdot 13) \\
1 \cdot 1 \pm 0.63^{a} \\
(0.11)\end{array}$ & $\begin{array}{c}0.4 \pm 0.44 \\
(0.04)\end{array}$ & $3 \cdot 07^{* *}$ \\
\hline
\end{tabular}

$\dagger$ Values marked with a superscript $a$ are not significantly different from the control at the $5 \%$ level. \$ Significant differences between wood types indicated by factorial analysis.

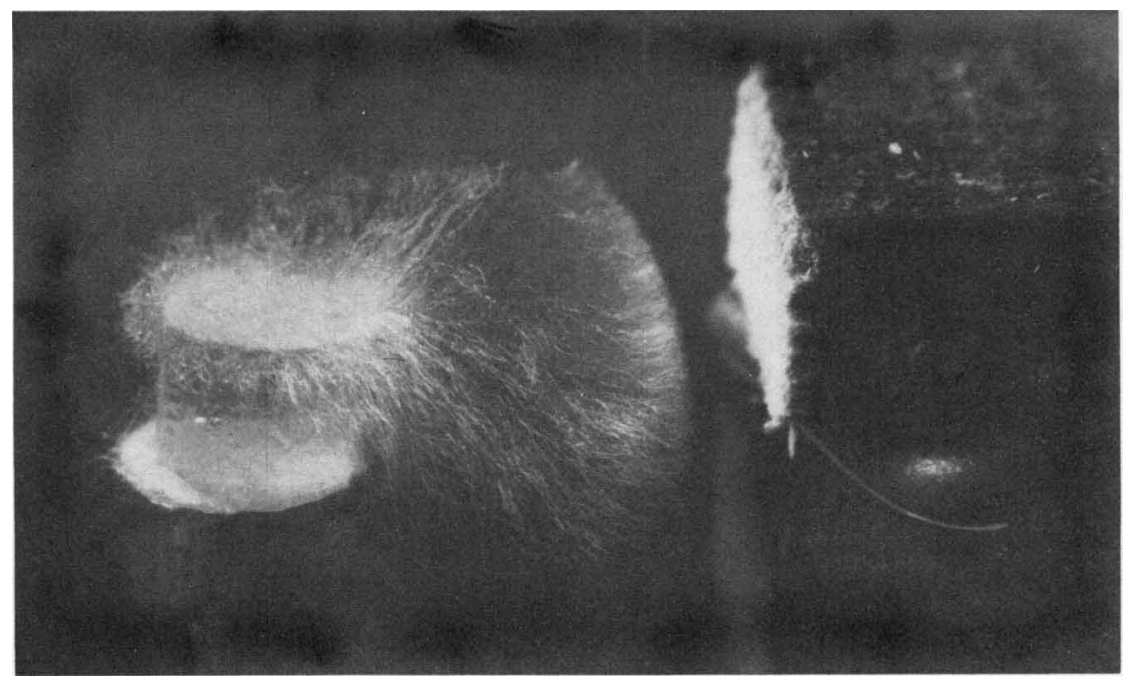

Fig. 3. Oriented hyphal extension of Chaetomium globosum towards heat-dried $\left(40^{\circ} \mathrm{C}\right)$ lime sapwood after $30 \mathrm{~h}$ incubation at $25^{\circ} \mathrm{C}$.

(Fig. 3) curvature of hyphae occurred on those sides away from the wood baits, thereby redirecting their growth towards the stimulus. Hyphal growth in S. lacrymans was inhibited on the sides of the colonies nearest to the wood blocks, major growth being directed away from the stimulus. These observations suggest that growth responses of some fungi to wood are not simply those of stimulation but rather tropic, by which changes in direction of growth take place in response to the stimulus. 
The model $Y=\gamma+\alpha \sin (X+\beta)$ is not an effective estimator of gross growth stimulation or inhibition when there is strong directionality involved in fungal growth. The large increases in hyphal extension on the side of the inoculum facing the block may be cancelled by corresponding decreases in hyphal length on the side of the inoculum away from the block and the parameter $\gamma$, the mean radius, is lowered. Furthermore $\alpha$ is not a meaningful indicator of differential growth unless its magnitude is related to mean colony radius. However, if the growth model is expressed in the form $Y=\gamma[1+\delta \sin (X+\beta)]$ where $\delta=\alpha / \gamma$, the value $\delta$ gives a dimensionless measure of differential growth. These values are also presented in Table 2 and also provide a useful comparative indicator for tropic response in fungi.

Gross stimulation of fungal growth in response to volatiles emanating from heated pine wood has been shown by several workers (Glasare, 1970; Flodin \& Fries, 1978) but it has also been shown that fresh pine or pine extracts such as terpenes inhibit growth (Shrimpton \& Whitney, 1968; Cobb et al., 1968; Hintikka, 1970; De Groot, 1972). Fries (1973), however, showed linear growth stimulation by some fungi to several terpenes. The experimental design used by Fries (1961), when he observed preferential growth of Polyporus applanatus towards a vessel containing nonanal, consisted of ventilated Petri dishes with containers holding the test compound at the periphery and a centrally inoculated organism. More recent investigations on the effects of volatiles on fungi (Shrimpton \& Whitney, 1968; Cobb et al., 1968; Hintikka, 1970; Flodin \& Fries, 1978) have been undertaken in sealed containers in which the atmosphere became saturated with volatile vapours, so that the organisms were equally stimulated or inhibited from all directions. Volatile concentration gradients would not be produced using such experimental systems, hence reducing the likelihood of observing oriented growth. In experiments carried out at this laboratory, inocula and baits were placed centrally in ventilated Petri dishes. Consequently, volatiles emanating from wood blocks would decrease in concentration from the wood-air interface to the periphery of the plate at which venting to the atmosphere is possible. Such gradients in volatile concentration would allow organisms, if chemotropic, to detect the source of volatiles, and Chaetomium globosum demonstrated oriented growth to wood baits placed up to $35 \mathrm{~mm}$ from inocula. The major effect of increasing bait distance was a diminution in density of aerial hyphae and oriented growth was maintained by these colonies.

Woody materials in soil are largely decomposed by fungal attack and susceptibility to decay is dependent on factors inherent in individual wood species and soils. Not least of these is the ability of decay organisms to make contact with nutrient resources. Mechanisms which enhance the incidence of contact are therefore highly advantageous as they reduce reliance on random coincidence between decay organisms and their substrates. In this context oriented and stimulated growth by fungi in response to wood volatiles may be of some importance in initiating microbial invasion of wood and would be of considerable ecological advantage in biologically competitive environments such as soil.

\section{REFERENCES}

Cobb, F. W., JR., Krstic, M., Zavarin, E. \& Barber, H. W., JR (1968). Inhibitory effects of volatile oleoresin components on Fomes annosus and four four Ceratocystis species. Phytopathology 58, 13271335 .

DE GROOT, R.C. (1972). Growth of wood-inhabiting fungi in saturated atmospheres of monoterpenes. Mycologia 64, 863-870.

FlodIN, K. \& FrIES, N. (1978). Studies on volatile compounds from Pinus silvestris and their effect on wood-decomposing fungi. II. Effects of some volatile compounds on fungal growth. European Journal of Forest Pathology 8, 300-310.

FRIES, N. (1961). The growth-promoting activity of some aliphatic aldehydes on fungi. Svensk botanisk tidskrift 55, 1-18.
FrIES, N. (1973). The growth-promoting activity of terpenoids on wood-decomposing fungi. European Journal of Forest Pathology 3, 169-180.

Glasare, P. (1970). Volatile compounds from Pinus silvestris stimulating the growth of wood-rotting fungi. Archiv für Mikrobiologie 72, 333-343.

Henningsson, B. \& Nilsson, T. (1976). Microbiological, microscopic and chemical studies of some salt-treated utility poles installed in Sweden in the years 1941-1946. In Soft-Rot in Utility Poles SaltTreated in the Years 1940-1954, pp. 1-25. Stockholm: Swedish Wood Preservation Institute Report No. $117 \mathrm{E}$.

HinTIKKA, V. (1970). Selective effect of terpenes on wood-decomposing Hymenomycetes. Karstenia 11, 28-32. 
King, B., SMith, G. M., BAECKer, A. A. W. \& BruCE, A. (1981). Wood nitrogen control of toxicity of copper chrome arsenic preservatives. Material und Organismen 16, 105-118.
Shrimpton, D. M. \& Whitney, H. S. (1968). Inhibition of growth of blue stain fungi by wood extractives. Canadian Journal of Botany 46, 757-761. 